\title{
Estimasi Emisi Gas Rumah Kaca pada Pengelolaan Sampah Domestik dengan Metode IPCC 2006 di TPA Talang Gulo Kota Jambi
}

\section{(Estimating Greenhouse Gas Emissions on Domestic Waste Management by IPCC 2006 Method in Talang Gulo Landfill, Jambi City)}

\author{
Winny Laura Christina Hutagalung ${ }^{1 *}$, Alfin Sakinah ${ }^{1}$, dan Rinaldi ${ }^{1}$ \\ ${ }^{1}$ Departemen Teknik Lingkungan, Fakultas Teknik, Universitas Jambi \\ J1. Tribrata KM. 11, Pondok Meja, Jambi \\ *Penulis korespondensi: winnylaura@yahoo.co.id
}

Diterima: 11 September 2019

Disetujui: 14 Februari 2020

\begin{abstract}
The waste that loaded to the Talang Gulo Landfill in 2018 was 1,012.2 $\mathrm{m}^{3} /$ day and is predicted to produce greenhouse gas (GHG) emissions such as $\mathrm{CH}_{4}$ and $\mathrm{N}_{2} \mathrm{O}$. The purpose of this study were to create a waste management layout, to determine the generation data and composition of waste in Jambi city and calculating the estimated amount of GHG. The calculation of GHG emissions in this study used Intergovernmental Panel on Climate Change (IPCC) 2006 method. Sampling results showed that the average waste generation in Jambi City was $20.7 \times 10^{-2} \mathrm{~kg} /$ person/day. Food, plastics, and paper wastes were the dominant components of waste in landfill, with the value of $47.4 \%, 20.6 \%$, and $13.1 \%$ respectively. $\mathrm{CH}_{4}$ emissions generated from landfill zone VI in 2019 amounted to $4.7 \times 10^{-2} \mathrm{Gg}$ and would increase to $16.6 \times 10^{-2} \mathrm{Gg}$ in 2030. Greenhouse gas emissions generated from the composting zone consisted of 8.6 $\times 10^{-4} \mathrm{Gg} \mathrm{CH}_{4}$ and $5.2 \times 10^{-5} \mathrm{Gg} \mathrm{N}_{2} \mathrm{O}$ in 2019 and would become $9.5 \times 10^{-4} \mathrm{Gg} \mathrm{CH}_{4}$ and $5.7 \times 10^{-5} \mathrm{Gg} \mathrm{N}_{2} \mathrm{O}$ in 2030. Emissions from heavy equipment activity in 2019 amounted to $1.1 \mathrm{Gg} \mathrm{CO}_{2}$. The estimation of greenhouse gas emissions are useful for taking steps to mitigate greenhouse gas emissions.
\end{abstract}

Keywords: composition, emissions, greenhouse gas, IPCC.

\section{PENDAHULUAN}

Masalah pengelolaan limbah padat (sampah) adalah tantangan terbesar bagi kota kecil dan besar di negara berkembang. Sampah menghasilkan sebagian besar emisi gas rumah kaca. Emisi gas rumah kaca menjadi masalah paling serius terhadap perubahan iklim global (Bogner, 2008). Perubahan iklim global akan meningkatkan suhu permukaan global sebesar $4.8{ }^{\circ} \mathrm{C}$ dan permukaan laut akan naik $0.82 \mathrm{~m}$ pada tahun 2100 (IPCC, 2006).

Kota Jambi memiliki fasilitas untuk me-nampung sampah yang dihasilkan masyarakat yaitu Tempat Pemrosesan Akhir (TPA) Talang Gulo Kota Jambi yang berada di Jalan Kebersihan RT. 04 Kelurahan Kenali Asam Bawah Kecamatan Kota Baru. Tempat
Pemrosesan Akhir (TPA) ini beroperasi sejak tahun 1997 dan memiliki 6 zona landfill. Sampah yang masuk pada tahun 2018 sebesar 1,012.2 $\mathrm{m}^{3} /$ hari (TPA Talang Gulo, 2018). Timbunan sampah yang masuk setiap harinya akan berpotensi untuk menghasilkan emisi Gas Rumah Kaca (GRK). Hasil penelitian di Kota Madiun menunjukkan bahwa aktivitas pengelolaan sampah zona penimbunan aktif di TPA Winongo yang memiliki luas $12,293 \mathrm{~m}^{2}$ dapat menghasilkan emisi $\mathrm{CH}_{4}$ 281,206 ton $\mathrm{CH}_{4} /$ tahun pada tahun 2015 (Kiswandayani, 2016).

Emisi gas rumah kaca dari zona penimbunan sampah di Tempat Pemrosesan Akhir (TPA) umumnya menghasilkan gas metana $\left(\mathrm{CH}_{4}\right)$. Sedangkan aktivitas zona pengomposan 
dapat menghasilkan Gas Rumah Kaca (GRK) berupa emisi $\mathrm{CH}_{4}$ dan $\mathrm{N}_{2} \mathrm{O}$. Selain itu, pengelolaan sampah di TPA juga menghasilkan emisi $\mathrm{CO}_{2}$ yang berasal dari aktivitas alat berat. Menurut Doorn dan Barlaz (1995), metana yang dihasilkan melalui proses dekomposisi anaerob dari sampah yang terkubur di dalam Tempat Pemrosesan Akhir (TPA) merupakan penyumbang yang signifikan terhadap emisi $\mathrm{CH}_{4}$ global, sekitar 10 sampai $70 \mathrm{Tg}$ /tahun. Emisi Gas Rumah Kaca (GRK) dari kegiatan pengelolaan sampah diperkirakan adalah sebesar 34\% dari total emisi GRK (Bogner, 2008).

Salah satu cara untuk memperkirakan emisi Gas Rumah Kaca (GRK) yang dihasilkan yaitu dengan menggunakan metode IPCC 2006 (Intergovernmental Panel on Climate Change). Metode ini menggunakan data hasil proyeksi jumlah penduduk, timbulan sampah, dan persentase pengelolaan sampah. Berdasarkan potensi emisi Gas Rumah Kaca (GRK) yang dihasilkan, perlu adanya usaha minimasi timbulan sampah agar jumlah emisi gas rumah kaca mengalami penurunan.

Penelitian ini bertujuan untuk mendapatkan komposisi sampah di Kota Jambi serta menghitung estimasi jumlah emisi gas rumah kaca pada zona penimbunan VI, zona pengomposan, dan aktivitas alat berat.

\section{METODOLOGI}

Penelitian ini dilakukan di Tempat Pemrosesan Akhir (TPA) Talang Gulo Kota Jambi selama 8 hari secara berturutturut. Penelitian dilakukan mulai dari 25 April 2019 sampai 2 Mei 2019. Pengambilan data primer terdiri dari beberapa tahapan, yaitu:

1. Penentuan titik pengambilan sampel

Titik pengambilan sampel adalah TPA Talang Gulo yang secara langsung menerima sampah domestik Kota Jambi. Pengambilan sampel dilakukan dari setiap truk secara acak (simple random sampling) dan tidak boleh dilakukan pemilahan terlebih dahulu. Simple random sampling ialah pengambilan anggota sampel dari populasi dilakukan secara acak tanpa memperhatikan tingkatan yang ada dalam populasi artinya suatu populasi memiliki kesempatan yang sama untuk dipilih menjadi sampel (Sugiyono, 2007; Triyono, 2018).

2. Pengambilan sampel dan penimbangan sam-pah sebelum dipilah

Berdasarkan SNI 19-3964-1994, frekuensi sampling yang ideal adalah setiap hari selama delapan hari berturutturut. Alat dan bahan yang akan digunakan dalam pengambilan sampel adalah sebagai berikut:

a. Box kayu berukuran 125 Liter

b. Masker dan sarung tangan

c. Sekop atau keranjang

d. Kantong plastik

e. Timbangan $30 \mathrm{~kg}$

Total volume sampel sampah yang akan diambil dalam 1 kali sampling adalah $1 \mathrm{~m}^{3}$ (1000 liter). Sampah diambil dari setiap truk dan di masukkan ke dalam kantong plastik sebelum dilakukan penimbangan. Penimbangan dilaku-kan untuk mengetahui berat sampah basah secara keseluruhan dari setiap truk.

3. Pemilahan sampel

Pemilahan sampel di TPA Talang Gulo dilakukan berdasarkan klasifikasi 11 komponen sampah menurut IPCC 2006 Guideline yang terdiri dari:

a. Sampah makanan

b. Sampah kebun

c. Sampah kayu

d. Sampah kertas dan karton

e. Sampah kain dan produk tekstil

f. Sampah nappies

g. Sampah karet dan kulit

h. Sampah plastik

i. Sampah logam

j. Sampah gelas

k. Sampah lain-lain 
4. Penimbangan sampah

Sampah yang telah dipilah berdasarkan klasifikasi kemudian dimasukkan ke dalam kantong plastik untuk dilakukan penimbangan menggunakan timbangan.

5. Perhitungan komposisi sampah

Komposisi sampah dinyatakan dalam persen berat basah dari setiap komponen sampah. Komposisi sampah akan digunakan sebagai acuan perhitungan tingkat emisi gas rumah kaca yang dihasilkan dari setiap komponen. Komposisi sampah tiap komponen dinyatakan dalam $\%$ berdasarkan persamaan sebagai berikut (Kementerian Lingkungan Hidup, 2012):

$\%$ berat basah $=\frac{\text { berat komponen sampah }}{\text { berat total keseluruhan sampah }} \times 100 \%$

Selain komposisi sampah dibutuhkan juga data densitas sampah. Densitas sampah atau massa jenis sampah merupakan perbandingan antara berat dan volume sampah. Selama penelitian 8 hari berturut-turut akan dilakukan pengukuran berat sampah dengan volume $1 \mathrm{~m}^{3}(1000$ L) dengan persamaan sebagai berikut:

Densitas sampah $=\frac{\text { Volume sampah }(\mathrm{L})}{\text { Berat sampah }(\mathrm{kg})}$

Analisa data dilakukan terhadap kegiatan di TPA Talang Gulo yaitu pada zona penimbunan, zona pengomposan dan alat berat.

1. Perhitungan emisi gas rumah kaca dari Zona Penimbunan VI

Emisi gas rumah kaca yang dihasilkan dari aktivitas penimbunan sampah adalah gas metana $\left(\mathrm{CH}_{4}\right)$. Perhitungan emisi gas metana menggunakan metode perhitungan emisi GRK pada pedoman IPCC 2006. Metode yang digunakan pada penelitian ini adalah metode FOD (First Order Decay).

$\mathrm{CH}_{4}=\left(\sum \mathrm{x}\right.$ CH generated $\left.\mathrm{x}, \mathrm{T}-\mathrm{RT}\right) \times(1-\mathrm{OXT})(3)$

Dimana:

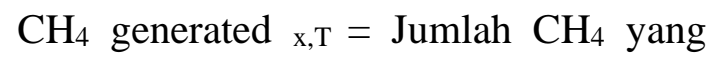
terbentuk pada tahun $\mathrm{T}$
$\mathrm{R}_{\mathrm{T}}=$ Recoveri $\mathrm{CH}_{4}$ untuk dimanfaatkan dalam tahun $\mathrm{T}$

$\mathrm{OX}_{\mathrm{T}}=$ Faktor oksidasi berdasarkan tipe TPA.

2. Perhitungan emisi gas rumah kaca dari Zona Pengomposan

Gas rumah kaca yang dihasilkan dari aktivitas pengomposan adalah gas $\mathrm{CH}_{4}$ dan $\mathrm{N}_{2} \mathrm{O}$.

$$
\begin{aligned}
\mathrm{CH}_{4} & =\sum\left((\mathrm{Mi} \times \mathrm{EFi}) \times 10^{-3}-R\right. \\
\mathrm{N}_{2} \mathrm{O} & =\sum\left((\mathrm{Mi} \times \mathrm{EFi}) \times 10^{-3}\right.
\end{aligned}
$$

Dimana:

Mi = Massa limbah organik yang diolah dengan pengolahan biologi tipe $\mathrm{i}$

$\mathrm{EFi}=$ Faktor emisi untuk pengolahan biologi tipe $\mathrm{i}$

$\mathrm{R}=$ Jumlah $\mathrm{CH}_{4}$ yang dapat direcoveri dalam tahun inventori.

3. Perhitungan emisi gas rumah kaca dari Alat Berat

Perhitungan emisi dari alat berat menggunakan rumus IPCC 2006.

$\mathrm{CO}_{2}=\mathrm{DA} \times \mathrm{FE}$

dimana

$\mathrm{DA}=$ data aktivitas $(\mathrm{TJ})$

$\mathrm{FE}=$ faktor emisi $\left(\mathrm{kg} \mathrm{CO}_{2} / \mathrm{TJ}\right)$

\section{HASIL DAN PEMBAHASAN}

\section{Pengelolaan Sampah di TPA Talang Gulo}

Tempat Pemrosesan Akhir (TPA) Talang Gulo berdiri sejak tahun 1997 dan berlokasi di Jalan Kebersihan RT. 04 Kelurahan Kenali Asam Bawah Kecamatan Kota Baru Kota Jambi. Lokasi Tempat Pemrosesan Akhir (TPA) berjarak sekitar $15 \mathrm{~km}$ dari pusat kota.

Sarana dan prasarana yang tersedia yaitu kendaraan dan alat-alat operasional. Kendaraan pengangkutan sampah dibagi menjadi 5 jenis kendaraan, yaitu 36 unit Dump Truck, 13 unit Arm Roll, 3 unit 
Dinas Lingkungan Hidup, 8 unit Patroli, dan 5 unit DISPERINDAG. Alat operasional yang digunakan yaitu 4 unit Excavator dan 2 Bullldozer dengan kondisi alat excavator jenis CAT $75 \%$, Komatshu PC 200-6 $70 \%$, Komatshu PC 200-8 85\%, dan Hitachi Rusak berat, sedangkan kondisi alat Bulldozer jenis CAT $80 \%$ dan Komatshu 85\%. TPA Talang Gulo menerima sampah yang dihasilkan masyarakat di Kota Jambi dengan luas lahan eksisting TPA 10 ha dan 21,3 ha sebagai cadangan. Saat ini, hanya zona VI yang menjadi satu-satunya zona aktif untuk menampung sampah Kota Jambi.

Sampah dari tempat penampungan sementara ( TPS ) diangkut ke tempat pemrosesan akhir (TPA) Talang Gulo menggunakan 4 jenis kendaraan. Setiap truk pengangkut sampah yang masuk ke TPA harus melalui loket pelaporan/pengambilan girek ritasi guna dicatat jumlah, jenis dan tanggal waktu pemasukan. Sampah yang akan dilakukan pengurugan atau penimbunan akan dibawa menuju zona penimbunan VI. Setelah semua sampah dibuang ke zona penimbunan VI, kendaraan akan keluar dari tempat pemrosesan akhir (TPA) untuk menunggu jadwal pengangkutan selanjutnya. Gambar 1 menunjukkan secara jelas alur pengelolaan sampah di tempat pemrosesan akhir (TPA) Talang Gulo.

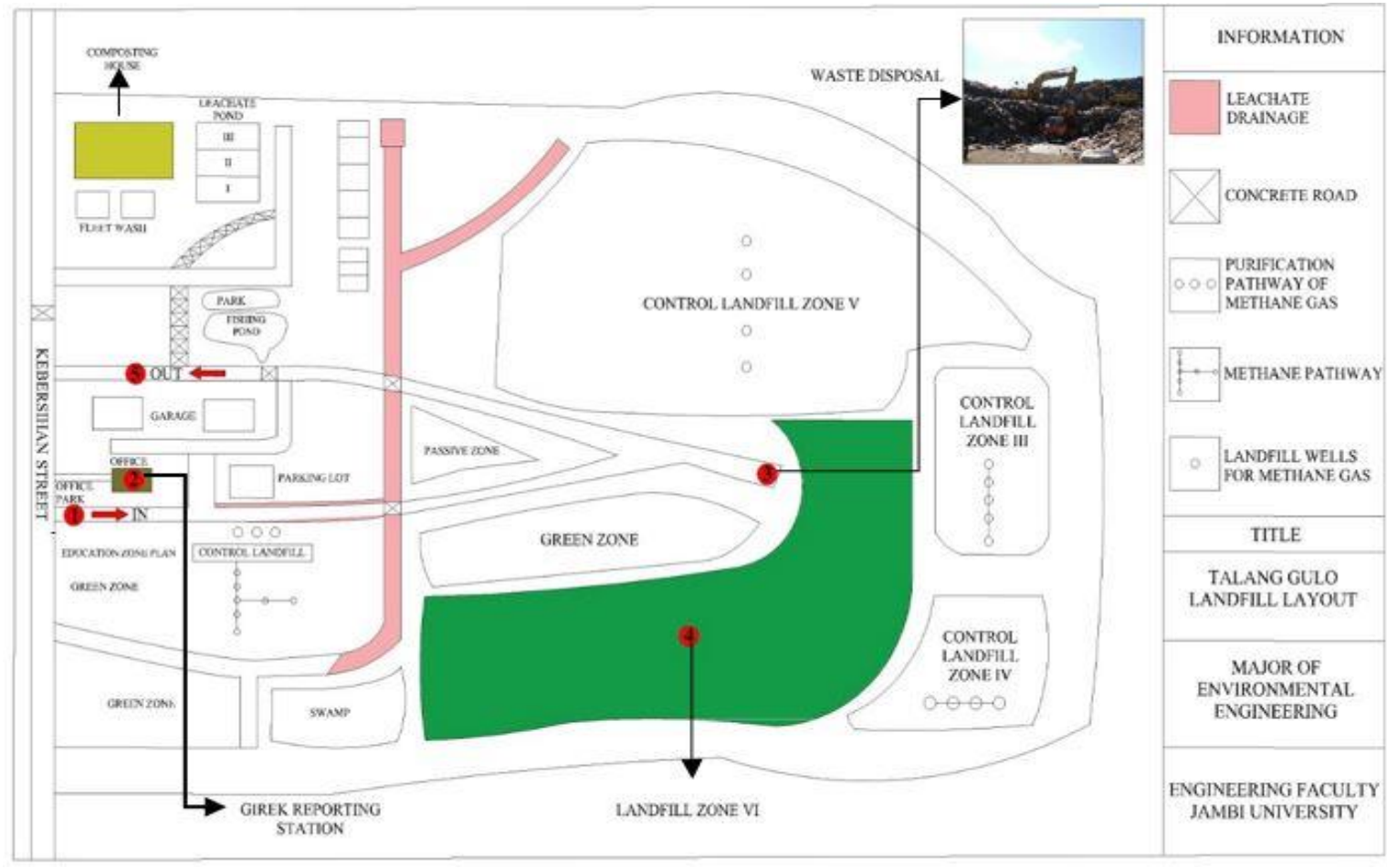

Gambar 1. Layout pengelolaan di TPA Talang Gulo

\section{Proyeksi Jumlah Penduduk dan Timbulan Sampah}

Dalam penelitian ini dibutuhkan data proyeksi jumlah penduduk Kota Jambi sebelum menghitung timbulan dan komposisi sampah tempat pemrosesan akhir (TPA) Talang Gulo. Proyeksi ditentukan berdasarkan data jumlah penduduk dan laju pertumbuhan penduduk yang diperoleh dari BPS Kota Jambi. Metode yang digunakan adalah metode aritmatik. Metode ini dipilih karena memiliki nilai korelasi yang paling mendekati 1 atau $=1$, sehingga 
metode ini memiliki hubungan yang sangat kuat atau mendekati kebenaran.

Berdasarkan hasil proyeksi jumlah penduduk pada Gambar 2 diketahui bahwa jumlah penduduk pada tahun 2019 sebanyak 602,537 jiwa dan pada tahun 2030 akan meningkat menjadi 665,253 jiwa. Data proyeksi penduduk akan digunakan untuk menghitung timbulan sampah yang dihasilkan oleh penduduk Kota Jambi setiap harinya. Data proyeksi penduduk dan data timbulan sampah merupakan data dasar dalam menentukan proyeksi banyaknya sampah yang dihasilkan oleh masyarakat Kota Jambi. Jumlah rata-rata sampah yang masuk ke TPA pada tahun 2018 dapat dihitung menggunakan data pada Tabel 1.

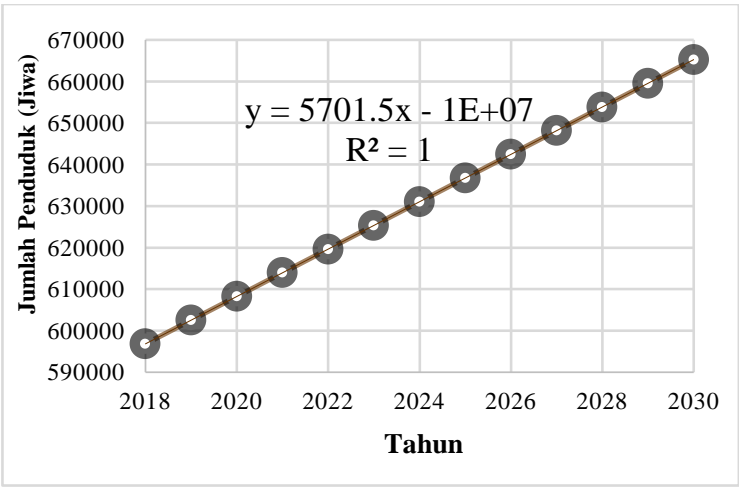

Gambar 2. Proyeksi Jumlah Penduduk Kota Jambi

Pada penelitian ini, sampling sampah dilakukan selama 8 hari berturut-turut untuk mendapatkan data densitas sampah. Densitas sampah atau massa jenis sampah merupakan perbandingan antara berat dan volume sampah. Didapatkan densitas sampah rata-rata sebesar $12.2 \times 10^{-2} \mathrm{~kg} / \mathrm{L}$.

Timbulan sampah diperoleh dari membagi volume sampah rata-rata dengan jumlah penduduk yang telah diketahui dan dikali dengan densitas sampah rata-rata.
Tabel 1.Volume Sampah yang Masuk ke TPA Talang Gulo Tahun 2018

\begin{tabular}{lcc}
\hline Bulan & $\begin{array}{l}\text { Sampah yang } \\
\text { Masuk TPA } \\
\left(\mathbf{m}^{3} / \mathbf{b u l a n}\right)\end{array}$ & $\begin{array}{l}\text { Sampah yang } \\
\text { Masuk TPA } \\
\left(\mathbf{m}^{\mathbf{3}} \mathbf{h a r i}\right)\end{array}$ \\
\hline Januari & $31,864.0$ & $1,027.9$ \\
\hline Februari & $27,726.0$ & 990.2 \\
\hline Maret & $30,693.5$ & 990.1 \\
\hline April & $29,761.0$ & 992.0 \\
\hline Mei & $30,881.5$ & 996.2 \\
\hline Juni & $30,455.5$ & $1,015.2$ \\
\hline Juli & $32,045.0$ & $1,033.7$ \\
\hline Agustus & $31,347.0$ & $1,011.2$ \\
\hline September & $30,088.0$ & $1,002.9$ \\
\hline Oktober & $31,585.5$ & $1,018.9$ \\
\hline November & $30,843.0$ & $1,028.1$ \\
\hline Desember & $32,252.0$ & $1,040.4$ \\
\hline Rata-rata & & $1,012.2$ \\
\hline
\end{tabular}

Sumber: TPA Talang Gulo, 2018.

Tabel 2 Proyeksi Timbulan Sampah Kota Jambi

Tahun Jumlah Laju Timbulan Timbulan Penduduk Timbulan Sampah Sampah (Jiwa) (kg/jiwa (kg/hari) (ton/tahun)

\begin{tabular}{ccccc} 
& \multicolumn{3}{c}{$\begin{array}{c}\text { /hari) } \\
\left(\mathbf{x 1 0} \mathbf{-}^{-2}\right)\end{array}$} \\
\hline 2018 & 596,835 & 20.7 & 123,545 & $45,093.9$ \\
\hline 2019 & 602,537 & 20.7 & 124,725 & $45,524.7$ \\
\hline 2020 & 608,238 & 20.7 & 125,905 & $45,955.4$ \\
\hline 2021 & 613,940 & 20.7 & 127,086 & $46,386.2$ \\
\hline 2022 & 619,641 & 20.7 & 128,266 & $46,816.9$ \\
\hline 2023 & 625,343 & 20.7 & 129,446 & $47,247.8$ \\
\hline 2024 & 631,044 & 20.7 & 130,626 & $47,678.5$ \\
\hline 2025 & 636,746 & 20.7 & 131,806 & $48,109.3$ \\
\hline 2026 & 642,447 & 20.7 & 132,987 & $48,540.1$ \\
\hline 2027 & 648,149 & 20.7 & 134,167 & $48,970.9$ \\
\hline 2028 & 653,850 & 20.7 & 135,347 & $49,401.6$ \\
\hline 2029 & 659,552 & 20.7 & 136,527 & $49,832.5$ \\
\hline 2030 & 665,253 & 20.7 & 137,707 & $50,263.2$
\end{tabular}

Sumber: Hasil Perhitungan, 2019.

\section{Komposisi Sampah}

Data komposisi sampah diperoleh dari sampling sampah selama 8 hari . Sampah yang digunakan untuk sampling sebanyak $1 \mathrm{~m}^{3}$ atau $1000 \mathrm{~L}$. 


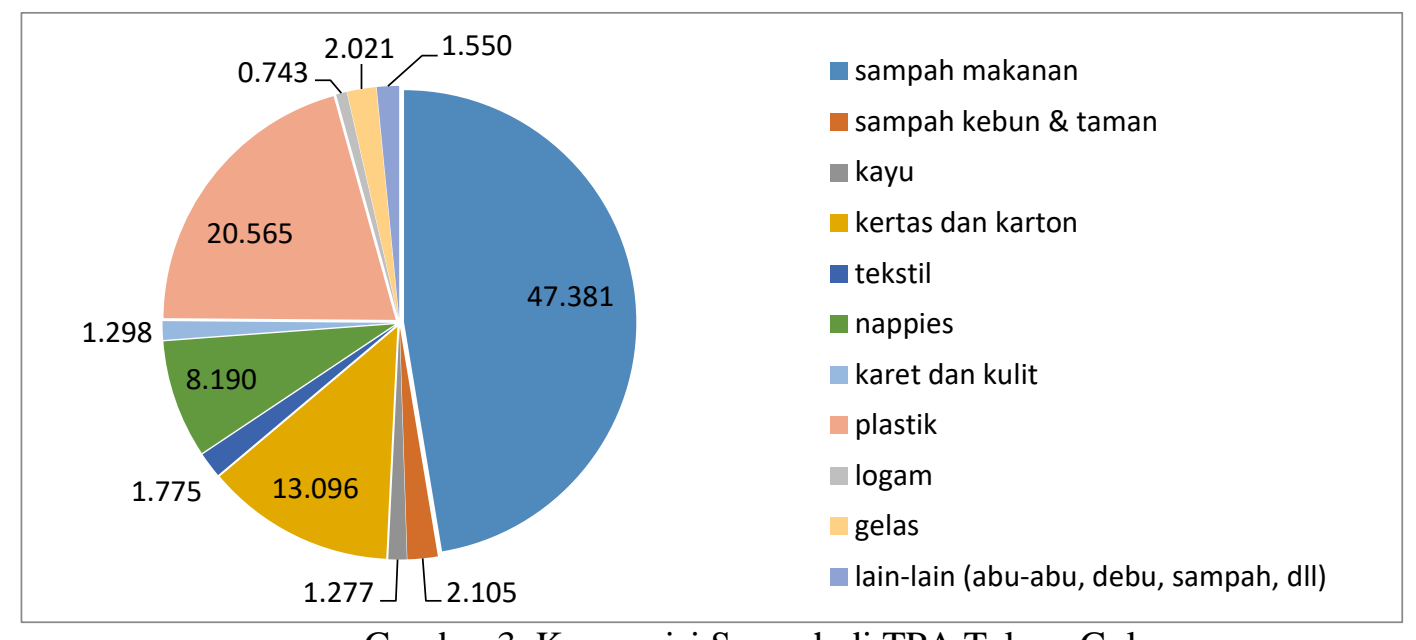

Gambar 3. Komposisi Sampah di TPA Talang Gulo

Dilakukan pemilahan untuk mendapatkan berat dari setiap jenis sampah menurut IPCC 2006. Komposisi sampah dinyatakan dalam satuan persen (\%). Komposisi sampah makanan tetap menjadi yang tertinggi karena sampah makanan dihasilkan dari sisa kebutuhan sehari-hari dari rumah tangga, pasar, dan restoran atau warung.

Komposisi sampah diperlukan untuk menentukan degradable organic carbon (DOC) yang akan memengaruhi emisi gas rumah kaca yang akan dihasilkan. Hasil perhitungan komposisi sampah di TPA Talang Gulo Kota Jambi disajikan pada Gambar 3.

\section{Estimasi Gas Rumah Kaca di Kota Jambi}

Untuk perhitungan emisi gas rumah kaca dibutuhkan berat sampah dari tahun 2018 hingga tahun 2030 berdasarkan timbulan sampah (Tabel 2) dan komposisi sampah (Gambar 3). Komponen sampah yang dibutuhkan untuk perhitungan emisi gas rumah kaca hanya berupa sampah organik yang terdiri dari 7 komponen yaitu sampah makanan, sampah kebun dan taman, sampah kayu, sampah kertas dan karton, sampah nappies, sampah kain dan tekstil, serta sampah karet dan kulit. Berat sampah tahun 2018-2030 dari setiap komponen dapat dilihat pada Tabel 3.
1. Emisi Gas Rumah Kaca (GRK) $\mathrm{CH}_{4}$ di Zona Penimbunan VI

Dalam penelitian ini difokuskan pada zona VI yang merupakan zona aktif di TPA Talang Gulo Kota Jambi pada tahun 2019. Prosedur perhitungan dilakukan untuk masing-masing komposisi sampah terlebih dulu kemudian diakumulasikan untuk semua jenis sampah.

Emisi $\mathrm{CH}_{4}$ yang dihasilkan dari zona penimbunan VI pada tahun 2019 sebesar $4.7 \times 10^{-2} \mathrm{Gg}$ dan akan meningkat menjadi $1.7 \times 10^{-1} \mathrm{Gg}$ pada tahun 2030 .

2. Emisi Gas Rumah Kaca (GRK) $\mathrm{CH}_{4}$ dan $\mathrm{N}_{2} \mathrm{O}$ di Zona Pengomposan

Pengolahan sampah pada zona pengomposan pada tahun 2018 sebesar $0.213 \mathrm{Gg}$ atau hanya sekitar $0.47 \%$ dari timbulan sampah. Zona pengomposan menghasilkan emisi gas rumah kaca $\mathrm{CH}_{4}$ dan $\mathrm{N}_{2} \mathrm{O}$ yang dapat dihitung menggunakan metode IPCC 2006. Tabel 4 menunjukkan bahwa emisi $\mathrm{CH}_{4}$ meningkat menjadi $9.5 \times 10^{-4} \mathrm{Gg}$ pada tahun 2030. Hasil proyeksi $\mathrm{N}_{2} \mathrm{O}$ juga mengalami peningkatan dimana tahun 2019 dihasilkan emisi $\mathrm{N}_{2} \mathrm{O}$ sebesar $5.2 \mathrm{x}$ $10^{-5} \mathrm{Gg}$ dan pada tahun 2030 menjadi 5.7 $\mathrm{x} 10^{-5} \mathrm{Gg}$. 
JSIL JURNAL TEKNIK SIPIL DAN LINGKUNGAN | Vol. 05 №. DI, April 2020

Tabel 3. Berat Sampah Tahun 2018-2030

\begin{tabular}{|c|c|c|c|c|c|c|c|c|c|}
\hline \multirow[t]{2}{*}{ Tahun } & \multirow{2}{*}{$\begin{array}{l}\text { Timbulan } \\
\text { sampah } \\
\text { (ton/tahun) }\end{array}$} & \multirow{2}{*}{$\begin{array}{l}\text { Timbulan sampah } \\
\text { (Ggram/Tahun) }\end{array}$} & \multicolumn{7}{|c|}{ Komponen Sampah (Ggram/Tahun) } \\
\hline & & & Makanan & Taman & Kayu & Kertas & Nappies & Tekstil & Karet \\
\hline 2018 & $45,093.9$ & 45.1 & 21.4 & 0.9 & 0.6 & 5.9 & 3.7 & 0.8 & 0.6 \\
\hline 2019 & $45,524.7$ & 45.5 & 21.6 & 1.0 & 0.6 & 5.9 & 3.7 & 0.8 & 0.6 \\
\hline 2020 & $45,955.4$ & 46.0 & 21.8 & 1.0 & 0.6 & 6.0 & 3.8 & 0.8 & 0.6 \\
\hline 2021 & $46,386.2$ & 46.4 & 22.0 & 1.0 & 0.6 & 6.1 & 3.8 & 0.8 & 0.6 \\
\hline 2022 & $46,816.9$ & 46.8 & 22.2 & 1.0 & 0.6 & 6.1 & 3.8 & 0.8 & 0.6 \\
\hline 2023 & $47,247.8$ & 47.2 & 22.4 & 1.0 & 0.6 & 6.2 & 3.9 & 0.8 & 0.6 \\
\hline 2024 & $47,678.5$ & 47.7 & 22.6 & 1.0 & 0.6 & 6.2 & 3.9 & 0.9 & 0.6 \\
\hline 2025 & $48,109.3$ & 48.1 & 22.8 & 1.0 & 0.6 & 6.3 & 3.9 & 0.9 & 0.6 \\
\hline 2026 & $48,540.1$ & 48.5 & 23.0 & 1.0 & 0.6 & 6.4 & 4.0 & 0.9 & 0.6 \\
\hline 2027 & $48,970.9$ & 49.0 & 23.2 & 1.0 & 0.6 & 6.4 & 4.0 & 0.9 & 0.6 \\
\hline 2028 & $49,401.6$ & 49.4 & 23.4 & 1.0 & 0.6 & 6.5 & 4.0 & 0.9 & 0.6 \\
\hline 2029 & $49,832.5$ & 49.8 & 23.6 & 1.0 & 0.6 & 6.5 & 4.1 & 0.9 & 0.7 \\
\hline 2030 & $50,263.2$ & 50.3 & 23.8 & 1.0 & 0.6 & 6.6 & 4.1 & 0.9 & 0.7 \\
\hline
\end{tabular}

Sumber: Hasil Perhitungan 2019.

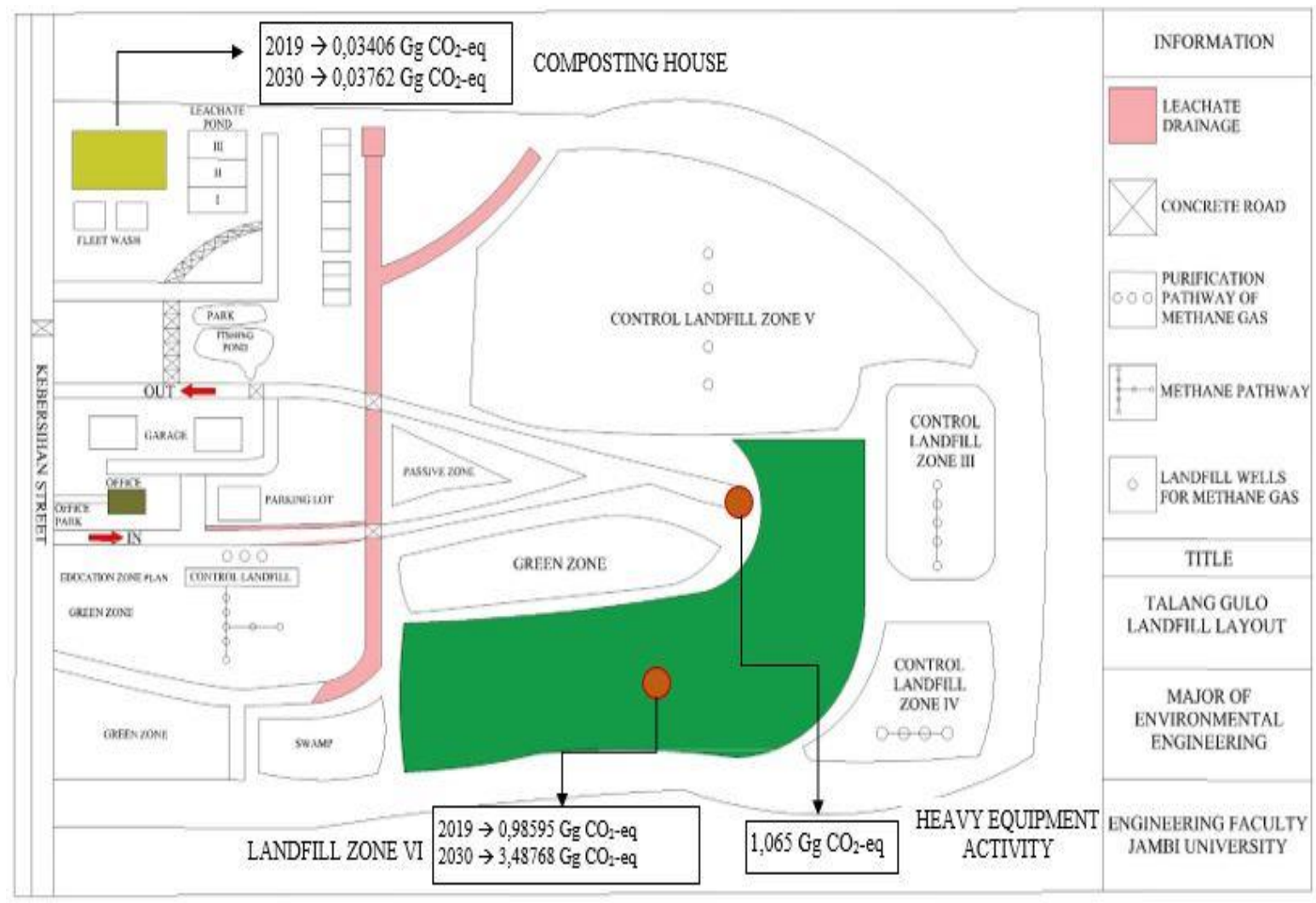

Gambar 4. Layout emisi gas rumah kaca TPA Talang Gulo 
Tabel 4. Emisi Gas Rumah Kaca Zona Pengomposan

\begin{tabular}{lccc}
\hline Tahun & $\begin{array}{c}\text { Jumlah Sampah } \\
\text { yang masuk ke } \\
\text { Zona } \\
\text { Pengomposan } \\
\left.(\mathbf{G g})(\mathbf{x 1 0})^{-1}\right)\end{array}$ & $\begin{array}{c}\text { Emisi } \\
\mathbf{C H}_{4} \\
\left(\mathbf{G g ~ C H}_{4}\right) \\
\left(\mathbf{x 1 0}^{-4}\right)\end{array}$ & $\begin{array}{c}\text { Emisi N2O } \\
\left(\mathbf{G g ~ N}_{2} \mathbf{O}\right) \\
\left(\mathbf{x 1 0}^{-5}\right)\end{array}$ \\
\hline $\mathbf{2 0 1 8}$ & 2.1 & 8.5 & 5.1 \\
\hline $\mathbf{2 0 1 9}$ & 2.2 & 8.6 & 5.2 \\
\hline $\mathbf{2 0 2 0}$ & 2.2 & 8.7 & 5.2 \\
\hline $\mathbf{2 0 2 1}$ & 2.2 & 8.8 & 5.3 \\
\hline $\mathbf{2 0 2 2}$ & 2.2 & 8.9 & 5.3 \\
\hline $\mathbf{2 0 2 3}$ & 2.2 & 8.9 & 5.4 \\
\hline $\mathbf{2 0 2 4}$ & 2.3 & 9.0 & 5.4 \\
\hline $\mathbf{2 0 2 5}$ & 2.3 & 9.1 & 5.5 \\
\hline $\mathbf{2 0 2 6}$ & 2.3 & 9.2 & 5.5 \\
\hline $\mathbf{2 0 2 7}$ & 2.3 & 9.3 & 5.6 \\
\hline $\mathbf{2 0 2 8}$ & 2.3 & 9.3 & 5.6 \\
\hline $\mathbf{2 0 2 9}$ & 2.4 & 9.4 & 5.7 \\
\hline $\mathbf{2 0 3 0}$ & 2.4 & 9.5 & 5.7 \\
\hline
\end{tabular}

Sumber: Hasil Perhitungan. 2019.

3. Emisi Gas Rumah Kaca (GRK) $\mathrm{CO}_{2}$ dari Alat Berat

Perhitungan emisi gas rumah kaca (GRK) dari aktivitas alat berat akan dilakukan berdasarkan metode IPCC 2006. Alat berat yang digunakan dalam pengelolaan sampah di TPA Talang Gulo terdiri dari excavator dan bulldozer. Excavator yang digunakan ada beberapa jenis yaitu CAT, Komatshu PC 200-6 dan Komatshu PC 200-8. Jenis Hitachi tidak digunakan dikarenakan dalam kondisi rusak berat. Bulldozer yang digunakan pada pengelolaan sampah hanya jenis Komatshu dikarenakan bulldozer jenis CAT sedang dilakukan perbaikan.

Estimasi emisi $\mathrm{CO}_{2}$ membutuhkan data konsumsi bahan bakar. nilai kalor. dan faktor emisi. Besaran konsumsi bahan bakar yang digunakan oleh setiap peralatan dinyatakan dalam satuan liter. Dalam hal ini konsumsi bahan bakar diperoleh melalui total jam kerja alat selama melakukan pekerjaan dikalikan konsumsi bahan bakar per jam. Konsumsi bahan bakar per jam untuk setiap alat diperoleh dari literatur karena data konsumsi bahan bakar sulit didapatkan.

Konsumsi bahan bakar yang digunakan berdasarkan penelitian Saefudin (2016) dimana penggunaan bahan bakar untuk excavator sebesar 20 L/jam dan bulldozer sebesar $21 \mathrm{~L} / \mathrm{jam}$. Hasil perhitungan menunjukkan bahwa emisi gas rumah kaca yang dihasilkan sebesar $1.1 \quad \mathrm{Gg} \quad \mathrm{CO}_{2} /$ tahun dan diasumsikan sama hingga tahun 2030.

\section{Pemetaan Emisi Gas Rumah Kaca}

Jumlah emisi gas rumah kaca yang telah dihitung sebelumnya akan ditampilkan dalam bentuk layout emisi gas rumah kaca tempat pemrosesan akhir (TPA) Talang Gulo. Emisi yang dihasilkan akan dikonversi menjadi $\mathrm{CO}_{2}$-eq. Untuk memudahkan dalam membandingkan dampak dari setiap emisi maka dipakai indeks potensi pemanasan global (global warming potential) seperti pada Gambar 4.

\section{KESIMPULAN}

Komposisi sampah Kota Jambi di tahun 2019 terdiri dari sampah makanan 47.4\%, sampah kebun dan taman $2.1 \%$, sampah kayu $1.3 \%$, sampah kertas dan karton $13.1 \%$, sampah tekstil $1.8 \%$, sampah sampah nappies $8.2 \%$, sampah karet dan kulit $1.3 \%$, sampah plastik $20.6 \%$, sampah logam $0.7 \%$, sampah gelas $2.0 \%$, dan sampah lain-lain $1.5 \%$. Emisi gas rumah kaca yang dihasilkan pada zona penimbunan. zona pengomposan dan alat berat. Emisi $\mathrm{CH}_{4}$ di zona penimbunan sebanyak $4.7 \times 10^{-2}$ $\mathrm{Gg}$ tahun 2019 dan mencapai $16.6 \times 10^{-2}$ $\mathrm{Gg}$ pada tahun 2030. Zona pengomposan: emisi $\mathrm{CH}_{4}$ dan $\mathrm{N}_{2} \mathrm{O}$ dengan jumlah emisi masing-masing sebanyak $8.6 \times 10^{-4} \mathrm{Gg}$ dan $5.2 \times 10^{-5} \mathrm{Gg}$ pada tahun 2019. Tahun 2030 dihasilkan emisi $\mathrm{CH}_{4}$ sebesar $9.5 \times 10^{-4} \mathrm{Gg}$ dan emisi $\mathrm{N}_{2} \mathrm{O}$ sebesar $5.7 \times 10^{-5} \mathrm{Gg}$. Emisi dari alat berat tahun 2019 sebesar $1.1 \mathrm{Gg} \mathrm{CO}_{2}$. 


\section{DAFTAR PUSTAKA}

Bogner J, Pipatti R, Hashimoto R, Diaz

C, Mareckova K, Diaz L, Kjeldsen P.S, Faaij A, Gao Q, Zhang T, Ahmed M.A, Sutamihardja. R.T.M, Gregory R. 2008. Mitigation of global GHG emissions from waste: conclusions and strategies from the Intergovernmental Panel on Climate Change (IPCC) Fourth Assessment Report. Working Group III (Mitigation). Waste Management Research 26. 11-13.

[BSN] Badan Standardisasi Nasional. SNI 19-3964-1994. 1994. Metode Pengambilan dan Pengukuran Contoh Timbulan dan Komposisi Sampah Perkotaan. Jakarta (ID). Badan Standardisasi Nasional.

[BSN] Badan Standardisasi Nasional. SNI 19-2454-2002. 2002. Tata Cara Teknik Operasional Pengelolaan Sampah Perkotaan. Jakarta(ID). Badan Standardisasi Nasional.

Doorn M.R.J., Barlaz MA. 1995. Estimate of Global Methane Emissions From Landfills And Open Dumps; Project Summary. NC (US). Air and Energy Engineering Research Laboratory. U.S. Environmental Protection Agency. Research Triangle Park..

[IPCC] Intergovernmental Panel on Climate Change 2006. IPCC Guidelines for National Greenhouse Gas Inventories: Volume 5-Waste. Prepared by The National Greenhouse Gas Inventories Programme. Eggleston H.S.. Buendia. L.. Miwa. K.. Ngara. T. and Tanabe. K. (eds.). Japan: IGES.

Kiswandayani A.T, Susnawati I.D, Wirosoedarmo, Ruslan. 2016. Komposisi Sampah dan Potensi Emisi Gas Rumah Kaca pada Pengelolaan Sampah Domestik:
Studi Kasus TPA Winongo Kota Madiun. Jurnal Sumber Daya Alam dan Lingkungan Vol. 2(3):917 Fakultas Teknologi Pertanian. Universitas Brawijaya. Malang.

[KLH] Kementerian Lingkungan Hidup. 2012. Pedoman Penyelenggaraan Inventarisasi Gas Rumah Kaca Nasional Buku II-volume I. Jakarta (ID). KLH.

Lestari J. A. 2017. Strategi Adaptasi dan Mitigasi Penurunan Emisi Gas Rumah Kaca (Grk) Sektor Transportasi Dan Sektor Persampahan di Kota Batu. Surabaya (ID). Institut Teknologi Sepuluh Nopember.

Mackie K. R, Cooper C.D. 2009. Landfill Gas Emission Prediction Using Voronoi Diagrams and Importance Sampling. Environmental Modelling \& Software 24 :1223-1232.

Prabowo S. P., Sri B. 2017. Estimasi Emisi Gas Rumah Kaca yang Dihasilkan dari Pembakaran Sampah di Jawa Tengah. Proceeding Biology Education Conference Vol. 14 (1): 187-194. Oktober 2017.

Saefudin A.H, Arif M, Puji W. 2016. Kajian Penggunaan Alat-Alat Berat pada Proyek Pembangunan Jalan Raya Ditinjau dari Aspek Teknis dan Ekonomi \{Studi Kasus Proyek Pembangunan Jalan Tol BOCIMI (Bogor. Ciawi. Sukabumi)\}. Bogor (ID). Fakultas Teknik. Universitas Pakuan Bogor. Sugiyono. 2007. Metode Penelitian Kuantitatif Kualitatif dan $R \& D$. Bandung(ID). Alfabeta.

[TPA] Tempat Pemrosesan Akhir Talang Gulo. 2018. Laporan Bulanan Sampah TPA Talang Gulo. Kota Jambi (ID).

Triyono. 2018. Teknik Sampling dalam Penelitian. Palangkaraya (ID). Universitas Palangkaraya 
JSIL ～Hutagalung, dkk. : Estimasi Emisi Gas Rumah Kaca pada Pengelolaan Sampah Domestik

Wijayanti. W.P. 2013. Peluang

Pengelolaan Sampah Sebagai

Strategi Mitigasi dalam

Mewujudkan Ketahanan Iklim

Kota Semarang. Jurnal

Pembangunan Wilayah dan Kota.

Vol 9 (2): 152-16 